\title{
TELAAH SOAL UJI COBA I BAHASA INDONESIA DI SMP KABUPATEN WONOSOBO \\ TAHUN 2013
}

\author{
Mushoffa dan Burhan Nurgiyantoro \\ SMP N 1 Leksono Kabupaten Wonosobo, Universitas Negeri Yogyakarta \\ mushoffahud@gmail.com/burhan@uny.ac.id
}

\begin{abstract}
Abstrak
Penelitian ini bertujuan untuk mendeskripsikan ketepatan indikator dalam kisikisi soal, keterwakilan setiap kompetensi dasar dalam soal, kesesuaian antara kisi-kisi soal dan soal, serta capaian daya serap setiap kompetensi dasar. Penelitian ini merupakan penelitian deskriptif kualitatif-kuantitatif. Subjek penelitian ini adalah kisi-kisi soal, soal, dan capaian daya serap dari soal uji coba I bahasa Indonesia di SMP kabupaten Wonosobo tahun 2013. Pengumpulan data dilakukan dengan teknik baca dan catat.Hasil penelitian ini adalah sebagai berikut: (1) ketepatan indikator dalam kisi-kisi soal termasuk kategori tepat $(86,4 \%)$ dengan rincian ketepatan indikator pada kategori sangat tepat sebesar $22 \%$, tepat sebesar $68 \%$, cukup tepat sebesar $8 \%$, kurang tepat sebesar $2 \%$, dan tidak tepat sebesar $0 \%$; (2) keterwakilan setiap kompetensi dasar dalam kisi-kisi soal uji coba I bahasa Indonesia Kabupaten Wonosobo dalam kategori sangat terwakili (96,7\%); (3) kesesuaian antara kisi-kisi soal dan soal uji coba I bahasa Indonesia Kabupaten Wonosobo tahun 2013 termasuk kategori sesuai (86\%); dan capaian daya serap untuk seluruh kompetensi dasar dalam soal uji coba I bahasa Indonesia Kabupaten Wonosobo tahun 2013 termasuk kategori rendah yaitu sebesar $56,89 \%$ dengan rincian capaian pada kategori sangat tinggi sebesar $0 \%$, tinggi sebesar 14\%, sedang sebesar $24 \%$, rendah sebesar $30 \%$, dan sangat rendah sebesar $32 \%$.
\end{abstract}

Kata Kunci: telaah, kisi-kisi soal, soal, daya serap

\section{THE ANALYSIS OF THE FIRST TRY OUT OF INDONESIAN LANGUAGE TEST IN JUNIOR HIGH SCHOOLS OF WONOSOBO REGENCY IN 2013}

\begin{abstract}
This study aims todescribe the accuracy ofthe indicatorsinthe table of specifications, the representation ofeachbasiccompetenceinthe table of specifications, the compatibility between table of specifications and test items, and the learning outcomes performanceof eachbasiccompetenceof the test items. This research is qualitativequantitative descriptive. The subjects were the table specifications, test items, and the learning outcomes performance of thefirst try out of Indonesian language test in junior high schools of Wonosobo regency in 2013. Data were collected through the reading and recording. The results are as follow. (1) the accuracy ofthe indicators in the table specifications at accurate category $(86,4 \%)$ withinthe accuracy of indicators at very good category $(22 \%)$, good category $(68 \%)$, medium category $(8 \%)$, low category $(2 \%)$, and very low category $(0 \%) ;(2)$ the representation ofeachbasiccompetenceinthe table specifications at very representive category $(96,7 \%)$; (3) the compatibility betweenthe table specifications and test items at compatible category ( $86 \%)$; and(4) the learning outcomes performance of all thebasiccompetencies are included in the low category $(56,89)$ within the learning outcomes performances at very good category $(0 \%)$, good category $(14 \%)$, medium category (24\%), low category (30\%), and very low category $(32 \%)$.
\end{abstract}

Keywords: analysis, table of specifications, tes items, learning outcomes. 


\section{A. PENDAHULUAN}

Pelaksanaan penilaian dalam kegiatan belajar mengajar dimaksudkan untuk mendapatkan informasi tentang keberhasilan pendidik mengajarkan materi pembelajaran serta kemampuan peserta didik dalam menyerap materi yang diajarkan. Pencapaian hasil belajar peserta didik dapat dilihat dari tingkat penguasaan materi oleh peserta didik. Untuk mengetahui keberhasilan atau prestasi peserta didik tersebut, pengukuran perlu diadakan secara cermat dan tepat. Kecermatan dan ketepatan dalam pengukuran sangat ditentukan oleh alat ukur yang dipakai.

Alat ukur soal ujian yang dibuat oleh guru tentunya harus disusun dengan cermat dan tepat. Untuk mengetahui ketepatan dan kecermatan soal ujian tersebut, diperlukan telaah soal ujian. Adapun tujuan utama telaah soal ujian diantaranya adalah untuk memperoleh informasi tentang ketepatan indikator dalam kisi-kisi soal, keterwakilan setiap kompetensi dasar, kesesuaian antara kisi-kisi soal dan butir soal, serta tingkat penguasaan peserta didik pada setiap kompetensi dasar yang diujikan. Dengan demikian, soal buatan guru yang sering dikatakan rendah atau tidak diketahui secara pasti kualitasnya dapat terjawab, sehingga pada perkembangannya soal yang dibuat dan digunakan guru betul-betul dapat mengukur apa yang seharusnya diukur.

Sudijono (2006:132) menyatakan bahwa tidaklah mungkin bagi tester untuk membuat butir-butir soal tes obyektif dengan secara mendadak atau terburu-buru. Kisi-kisi soal dan butir soal uji coba I bahasa Indonesia di SMP Kabupaten Wonosobo dibuat oleh tim penyusun soal Musyawarah Guru Mata Pelajaran (MGMP). Penyusunan kisi-kisi dan soal uji coba dilaksanakan dalam waktu 2 hari. Pemberitahuan kepada pembuat soal biasanya juga disampaikan dalam waktu yang sudah dekat dengan waktu penyusunan soal. Dengan demikian, kemungkinan adanya kesalahan-kesalahan pada kisi-kisi dan soal tersebut sangatlah beralasan.

Kisi-kisi sangat dibutuhkan dalam penyusunan alat tes yang baik. Nurgiyantoro (2012:79) menjelaskan bahwa kisi-kisi adalah sebuah cetak biru (blue print), perencanaan, yang dijadikan pedoman untuk pembuatan dan perakitan soal-soal ujian. Fungsi kisi-kisi ada- lah mengontrol butir-butir soal. Tiap butir soal secara jelas harus mengukur suatu indikator, dan tiap-tiap indikator harus ada butir soalnya. Artinya, telaah terhadap kisi-kisi soal sangat terkait dengan perumusan indikator serta keterwakilan setiap indikator dan kompetensi dasar yang dikembangkan. Setiap kompetensi dasar dapat diwakili oleh satu indikator atau lebih. Hal ini disesuaikan dengan keluasan cakupan materi yang dikandung setiap kompetensi dasar (KD). Jumlah soal juga disesuaikan dengan indikatorindikator yang dikembangkan dari kompetensi dasarnya.

Fives \& Barnes (2013) dalam penelitiannya mengungkapkan bahwa tes kelas dapat memberikan informasi penting yang dapat digunakan bagi guru dalam menentukan keputusan tentang pembelajaran dan nilai siswa. Penggunaan kisi-kisi soal dapat membantu guru dalam pengambilan keputusan yang terkait dengan penyusunan tes. Kisi-kisi soal juga dapat meningkatkan validitas evaluasi yang dilakukan guru dalam penyusunan tes kelas.

Kisi-kisi soal dibuat dalam beberapa langkah. Mardapi (2008:90) menyatakan bahwa ada empat langkah dalam mengembangkan kisi-kisi tes, yaitu menentukan tujuan umum pembelajaran, membuat daftar pokok bahasan dan subpokok bahasan yang akan diujikan, menentukan indikator, dan menentukan jumlah soal tiap pokok bahasan dan subpokok bahasan. Terkiat dengan indikator, Uno (2012, p.42) menyatakan bahwa indikator merupakan ukuran, karakteristik, ciri-ciri, pembuatan atau proses yang berkontribusi/menunjukkan ketercapaian suatu kompetensi dasar.

Alat tes tentunya harus berkualitas baik. Sudijono (2006:93-97) menyampaikan bahwa soal yang baik harus valid, reliabel, objektif, dan ekonomis-praktis. Thorndike \& ChristThorndike (2010:276-278) menyatakan bahwa prinsip-prinsip umum untuk soal-soal objektif adalah bacaan dan kosakata dalam soal-soal tes dibuat dengan singkat dan jelas, setiap item memiliki jawaban yang benar atau paling benar, pilihan setiap item merupakan bagian penting dari area konten, bukan hal-hal sepele, setiap item tidak bergantung pada yang lain, hindari penggunaan pertanyaan yang menjebak, dan permasalahan yang dimunculkan jelas dan tidak ambigu. 
Ada beberapa hal yang juga harus dihindari dalam penyusunan soal tes. Gronlund (1998:46) menyatakan bahwa ada beberapa rintangan yang dapat mengganggu siswa untuk menemukan jawaban yang benar. Beberapa rintangan yang harus dihindari pada saat mempersiapkan soal tes adalah penggunaan kosakata yang terlalu sulit, struktur kalimat yang terlalu kompleks, pernyataan-pernyataan yang bersifat ambigu, bahan-bahan gambar yang tidak sesuai, dan perintah yang tidak jelas.

Tes digunakan untuk mengukur keberhasilan guru dalam membelajarkan kompetensi dasar dan kemampuan siswa dalam menyerap materi pembelajaran dari kompetensi dasar. Depdiknas (2007:7) memberikan ketentuan bahwa kompetensi dasar adalah kemampuan minimal yang harus dikuasai siswa setelah mempelajari materi pelajaran tertentu. Telaah terhadap daya serap diperlukan untuk mengetahui kompetensi dasar apa saja yang masih menjadi kesulitan bagi peserta didik. Hal ini terkait dengan daya serap peserta didik terhadap soal uji coba I bahasa Indonesia Kabupaten Wonosobo tahun 2013 yang tergolong rendah, yaitu sebesar $56,9 \%$. Padahal daya serap setiap kompetensi dasar dikatakan tercapai jika sebesar 75\%.

Telaah terhadap ketepatan indikator dalam kisi-kisi soal, keterwakilan setiap kompetensi dasar, kesesuaian antara kisi-kisi soal dan soal, serta capaian daya serap setiap kompetensi dasar belum dilakukan. Telaah terhadap beberapa hal tersebut sebenarnya penting untuk dilakukan. Apabila alat-alat tes telah disusun dengan tepat, informasi yang didapat dari hasil tes tersebut juga benar dan sangat berguna bagi guru dalam proses pembelajaran pada tahap selanjutnya.

\section{B. METODE PENELITIAN}

Penelitian ini merupakan penelitian deskriptif kualitatif-kuantitatif, yakni penelitian yang berusaha menggambarkan dan menjelaskan suatu fenomena didasari dengan perhitungan angka-angka. Sukardi (2011:157) menjelaskan bahwa penelitian deskriptif merupakan metode penelitian yang berusaha untuk menggambarkan dan menginterpretasi objek sesuai dengan apa adanya.
Penelitian ini dilaksanakan di SMP kabupaten Wonsoobo pada bulan Agustus sampai dengan Oktober 2013.Instrumen utama dalam penelitian ini adalah peneliti sendiri (intrarater). Dengan pengetahuan, kepekaan, kecermatan, dan ketelitian, peneliti menggali dan menemukan data-data yang diperlukan sesuai dengan permasalahan penelitian. Data penelitian ini adalah ketepatan indikator, keterwakilan setiap kompetensi dasar, kesesuaian antara kisi-kisi soal dan soal, serta capaian daya serap. Data tersebut dikumpulkan melalui teknik baca dan catat. Instrumen lain yang digunakan dalam kegiatan pengumpulan data penelitian ialah lembar telaah, check list, kriteria, dan rubrik penilaian. Data hasil penelitian dimintakan pertimbangan kepada expert dan teman sejawat (interrater).

\section{HASIL PENELITIAN}

Hasil penelitian ini mendeskripsikan ketepatan indikator soal, keterwakilan setiap kompetensi dasar, kesesuaian antara kisi-kisi soal dan soal, serta capaian daya serap setiap kompetensi dasar. Adapun hasil penelitian adalah sebagai berikut.

\section{Ketepatan Indikator}

Ketepatan indikator dalam kisi-kisi soal uji coba I bahasa Indonesia di SMP Kabupaten Wonosobo dikelompokkan dalam lima skala kategori, yaitu sangat tepat, tepat, cukup tepat, kurang tepat, dan tidak tepat. Hasil telaah terhadap ketepatan indikator dalam kisi-kisi soal tersebut dapat dilihat dalam Tabel 1.

Tabel 1. Ketepatan Indikator

\begin{tabular}{clcc}
\hline No. & Kategori & $\begin{array}{c}\text { Jumlah } \\
\text { Indikator }\end{array}$ & $\begin{array}{c}\text { Persen- } \\
\text { tase }\end{array}$ \\
\hline 1. & Sangat Tepat & 11 & 22 \\
2. & Tepat & 34 & 68 \\
3. & Cukup Tepat & 4 & 8 \\
4. & Kurang Tepat & 1 & 2 \\
5. & Tidak Tepat & - & - \\
& Jumlah & 50 & 100 \\
\hline
\end{tabular}

Dari tabel tersebut dapat diketahui bahwa ketepatan indikator termasuk kategori tepat. Hal ini jelas dapat dilihat dari besaran persentase pada kategori sangat tepat dan tepat yangjumlahnya besar. Tidak ada indikator yang 
termasuk kategori tidak tepat. Ketepatan indikator tersebut didasarkan pada lima aspek, yaitu tingkat kompetensi, materi, kalimat, logika, dan kata kerja operasional. Hasil telaah terhadap kelima aspek tersebut dapat dilihat pada Tabel 2.

Tabel 2. Rincian Ketepatan Indikator per Aspek

\begin{tabular}{clc}
\hline No. & \multicolumn{1}{c}{ Aspek } & $\begin{array}{c}\text { Rata-rata } \\
\text { Ketepatan } \\
(\%)\end{array}$ \\
\hline 1. & Tingkat kompetensi & 99,3 \\
2. & Materi & 97,3 \\
3. & Kalimat & 85,3 \\
4. & Logika & 77,3 \\
5. & Kata Kerja Operasional & 73,3 \\
\multicolumn{2}{c}{ Rata-rata Keseluruhan } & $\mathbf{8 6 , 4}$ \\
\hline
\end{tabular}

Berdasarkan tabel tersebut, rata-rata ketepatan indikator untuk seluruh aspek sebesar $86,4 \%$. Hal ini berarti ketepatan indikator dalam kisi-kisi soal uji coba I bahasa Indonesia di SMP kabupaten Wonosobo termasuk dalam kategori tepat.

\section{Ketepatan Indikator dari Aspek Tingkat Kompetensi}

Ketepatan indikator dari aspek tingkat kompetensi mencapai 99,3\%. Hal ini berarti ketepatan tingkat kompetensi termasuk kategori sangat tepat. Ketepatan ini didasarkan pada tuntutan kata kerja kompetensi yang disesuaikan dengan perilaku-perilaku kognitif untuk jenis soal pilihan ganda. Perilaku kognitif yang tepat terdapat pada 49 indikator, sedangkan yang tidak tepat ada 1 indikator. Beberapa perilaku kognitif yang tepat tersebut adalah menentukan (42 soal), menyusun ( 1 soal), dan melengkapi (6 soal). Adapun satu tuntutan perilaku kompetensi yang tidak tepat adalah menjelaskan. Kata tersebut termasuk dalam tingkat kompetensi psikomotor, bukan kognitif.

\section{Ketepatan Indikator dari Aspek Materi}

Ketepatan indikator dari aspek materi mencapai 97,3\%. Hal ini berarti ketepatan materi juga termasuk kategori sangat tepat. Ketepatan materi didasarkan pada cakupan materi. Surapranata (2005:33) menyatakan bahwa indikator merupakan karakteristik, ciri- ciri, perbuatan, dan respon peserta didik yang menjadi acuan atas kemampuan yang hendak diukur. Indikator mencakup materi yang sangat spesifik dan lebih sempit. Hasil penelitian menunjukkan bahwa materi yang tepat terdapat pada 46 indikator, cukup tepat sebanyak 4 indikator, dan tidak ada materi yang tidak tepat. Artinya, 92\% materi telah spesifik dan ada 8\% materi yang belum spesifik. Contoh materi yang belum spesifik tersebut terdapat pada indikator soal nomor 6 .

(1) Disajikan sebuah iklan, siswa dapat menentukan kalimat fakta/opini dalam iklan tersebut.

Pada contoh indikator tersebut, materi masih belum spesifik, yaitu antara fakta ataukah opini. Salah satu dari kedua materi tersebut sebaiknya dihilangkan saja. Alternatif perbaikan untuk indikator tersebut sesuai dengan soal adalah sebagai berikut.

(1a) Disajikan sebuah iklan, siswa dapat menentukan kalimat fakta dalam iklan tersebut. Atau jika tanpa stimulus menjadi,

(1b) Siswa dapat menentukan kalimat fakta dalam iklan yang disediakan.

\section{Ketepatan Indikator dari Aspek Kalimat}

Ketepatan indikator dari aspek kalimat mencapai $85,3 \%$. Hal ini berarti ketepatan kalimat termasuk kategori tepat. Ketepatan kalimat didasarkan pada susunan gramatikal dan kejelasan maksud. Rahardi (2009, p.129) mengungkapkan bahwa kalimat efektif adalah kalimat yang memiliki kemampuan menimbulkan gagasan kembali atau pikiran pada diri pendengar atau pembaca, seperti apa yang ada dalam pikiran pembicara atau penulisnya. Melalui kalimat yang efektif, gagasan penulis atau pembicara itu akan dapat diterima secara utuh. Hasil penelitian menunjukkan bahwa kalimat yang tepat terdapat dalam 28 indikator, cukup tepat sebanyak 22 indikator, dan tidak ada kalimat indikator yang tidak tepat. Artinya, beberapa kalimat yang termasuk kategori cukup tepat perlu diperbaiki. Perbaikan beberapa kalimat indikator tersebut terkait dengan empat hal: kelengkapan unsur kalimat, kehematan kalimat, kejelasan maksud, dan kejelasan materi. 


\section{Kelengkapan Unsur Kalimat}

Kelengkapan unsur-unsur yang membangun sebuah kalimat sangat penting. Ketidakhadiran sebuah kata dalam suatu kalimat dapat menyebabkan ketidakutuhan maksud yang dikandungnya. Contoh kalimat indikator yang tidak lengkap terdapat pada indikator soal nomor 15.

(2) Disajikan kutipan puisi, siswa dapat menentukan perbedaan pesan.

Pada contoh indikator tersebut, ada kata yang tidak dihadirkan yaitu kata 'dua' sebelum kata 'kutipan'. Alternatif perbaikan untuk indikator tersebut adalah sebagai berikut.

(2a) Disajikan dua kutipan puisi, siswa dapat menentukan perbedaan pesan kedua kutipan puisi tersebut.

Atau jika tanpa stimulus menjadi,

(2b) Siswa dapat menentukan perbedaan pesan dua kutipan puisi yang disajikan.

\section{Kehematan Kalimat}

Kalimat yang efektif biasanya berupa kalimat yang singkat dan jelas. Kalimat tidak menggunakan kata-kata yang mubazir atau dipandang tidak perlu. Akhadiah, Arsjad \& Ridwan (2004:125) menyatakan bahwa unsur penting yang perlu diperhatikan dalam pembentukan kalimat efektif ialah kehematan. Ada beberapa kalimat indikator yang kurang hemat. Maksud penulis dalam kalimat sudah dapat diterima oleh pembaca, tetapi unsur bahasa yang digunakan sebenarnya bisa disederhanakan. Contoh ketidakhematan kalimat terdapat dalam indikator soal nomor 42.

(3) Disajikan kalimat tidak efektif, siswa dapat menentukan perbaikannya.

Pada contoh kalimat indikator tersebut, kata 'menentukan perbaikannya' dapat disederhanakan dengan kata 'memperbaiki/ menyunting'saja. Alternatif perbaikan untuk indikator tersebut adalah sebagai berikut.

(3a) Disajikan kalimat tidak efektif, siswa dapat menyuntingnya.

Atau jika tanpa stimulus menjadi,

(3b) Siswa dapat menyunting kalimat tidak efektif yang disajikan.

\section{Kejelasan Maksud}

Kejelasan maksud merupakan hal penting dari suatu kalimat. Kalimat tidak menimbulkan interpretasi yang berbeda. Interpretasi terhadap maksud kalimat yang berbeda ini sering disebut kalimat ambigu. Setyawati (2010:66) menyatakan bahwa ambiguitas adalah kegandaan arti kalimat, sehingga meragukan atau sama sekali tidak dipahami orang lain. Salah satu contoh ambiguitas adalah indikator kisi-kisi soal nomor 30 .

(4) Disajikan kutipan surat dinas yang bagian penutupnya dirumpangkan, siswa dapat menentukan kelengkapan bagian penutupnya".

Pada contoh kalimat indikator tersebut, ada ambiguitas pada unsur kalimat kelengkapan bagian penutupnya. Kelengkapan bagian penutup bisa disalahartikan menjadi unsur-unsur dari kalimat penutup saja, bukan kalimat penutup secara utuh. Padahal, maksud penyusun kisi-kisi soal adalah agar bagian (kalimat) penutup yang dirumpangkan itu harus dilengkapi. Alternatif perbaikan untuk indikator tersebut adalah sebagai berikut.

(4a) Disajikan sebuah kutipan surat dinas yang bagian penutupnya dirumpangkan, siswa dapat melengkapi bagian penutup tersebut dengan kalimat yang tepat.

Atau jika tanpa stimulus menjadi,

(4b) Siswa dapat melengkapi surat dinas yang dirumpangkan bagian penutupnya dengan kalimat yang tepat.

\section{Kejelasan Materi}

Materi merupakan bagian dari indikator. Materi harus jelas dan terbatas (spesifik). Salah satu contoh ketidakjelasan materi terdapat dalam indikator kisi-kisi soal nomor 21.

(5) Disajikan dua buah kutipan novel, siswa dapat menentukan perbedaan unsur intrinsik/ekstrinsik dua novel tersebut.

Pada contoh kalimat indikator tersebut, ada dua buah materi yaitu unsur intrinsik dan ekstrinsik. Dua unsur tersebut masing-masing masih memiliki cakupan yang luas. Unsur mana yang harus dijadikan soal oleh penulis soal masih belum jelas. Seharusnya penyusun kisi-kisi soal menentukan materi yang masih sangat luas tersebut menjadi materi yang sangat 
spesifik dan terbatas. Misalnya, unsur intrinsik yang dibatasi pada bagian sudut pandang saja. Jadi, alternatif perbaikan untuk indikator soal tersebut adalah sebagai berikut.

(5a) Disajikan dua buah kutipan novel, siswa dapat menentukan perbedaan sudut pandang dari kedua novel tersebut.

Atau jika tanpa stimulus menjadi,

(5b) Siswa dapat menentukan perbedaan sudut pandang dari dua novel yang disajikan.

\section{Ketepatan Indikator dari Aspek Logika}

Keraf (2004:54) menyatakan bahwa segi penalaran atau logika turut menentukan baik-tidaknya kalimat seseorang dan mudah tidaknya pikirannya dapat dipahami. Bahasa tidak bisa lepas dari penalaran.

Ketepatan logika yang dimaksudkan dalam penelitian ini adalah kesesuaian secara logis antara kompetensi, materi, dan unsur penyusun kalimat dalam indikator kisi-kisi soalnya. Berdasarkan hasil telaah yang dilakukan, rata-rata ketepatan indikator dari aspek logika termasuk dalam kategori cukup tepat $(77,3 \%)$. Beberapa hal yang menyebabkan tingkat ketepatan logika dalam kategori cukup tepat adalah adanya kekurangsesuaian antara kompetensi dan materi. Selain itu, kekurangsesuaian juga disebabkan oleh adanya kerancuan unsur-unsur penyusun kalimatnya. Sebuah contoh kategori logika yang cukup tepat adalah indikator kisikisi soal nomor 1 .

(6) Disajikan sebuah paragraf, siswa dapat menentukan gagasan utama paragraf tersebut.

Secara logika, gagasan utama biasanya diperoleh melalui sebuah proses pencarian lalu penemuan. Proses perilaku yang diminta dan terjadi sebenarnya adalah perilaku (kompe-tensi) penemuan, meskipun pada akhirnya perilaku (kompetensi) menentukan juga harus dilakukan. Akan tetapi, perilaku utama yang mendominasi adalah menemukan, bukan menentukan. Dengan demikian, alternatif perbaikan untuk indikator soal tersebut adalah sebagai berikut.

(6a) Disajikan sebuah paragraf, siswa dapat menemukan gagasan utama paragraf tersebut.

Atau jika tanpa stimulus menjadi, (6b) Siswa dapat menemukan gagasan utama suatu paragraf.

Adapun sebuah contoh ketidaktepatan logika terdapat pada indikator soal nomor 31 . Indikator tersebut adalah sebagai berikut.

(7) Disajikan surat pembaca tentang lingkungan yang tidak nyaman yang dirumpangkan, siswa dapat menentukan kalimat lengkapnya.

Pada kalimat tersebut setidaknya ada dua hal yang tidak logis yaitu pada bagian lingkungan yang tidak nyaman yang dirumpangkan dan pada bagian menentukan kalimat lengkapnya. Pada kedua bagikan tersebut dapat memunculkan kerancuan dan kesalahan logika. Oleh karena itu, alternatif perbaikan untuk indikator soal tersebut adalah sebagai berikut.

(7a) Disajikan surat pembaca tentang lingkungan yang tidak nyaman dan dirumpangkan salah satu bagian kalimatnya, siswa dapat melengkapinya dengan kalimat yang tepat.

Atau jika tanpa stimulus menjadi,

(7b) Siswa dapat melengkapi surat pembaca yang dirumpangkan dengan kalimat yang tepat.

\section{Ketepatan Indikator dari Aspek Kata Kerja Operasional}

Indikator dipergunakan sebagai dasar untuk membuat soal ujian. Oleh karena itu, indikator harus dirumuskan dengan mempergunakan kata kerja operasional, yaitu kata kerja yang kadar capaiannya dapat diukur atau diamati. BSNP (2010:3) memberikan ketentuan bahwa indikator dikembangkan sesuai dengan karakteristik peserta didik, mata pelajaran, satuan pendidikan, potensi daerah dan dirumuskan dalam kata kerja operasional yang terukur dan/ atau dapat diobservasi.

Berdasarkan hasil telaah, penggunaan kata kerja operasional dalam indikator soal tergolong cukup tepat. Hasil penghitungan ratarata ketepatan kata kerja operasional sebesar $73,3 \%$. Tingkat ketepatan tersebut dipengaruhi oleh ketepatan makna dan keefektifan kata-kata kerja operasional tersebut. Ketepatan makna berarti ada kesesuaian antara kata kerja operasional dengan perilaku (kompetensi). Adapun 
keefektifan berarti kata kerja operasional secara singkat dan tepat menggambarkan perilaku (kompetensi) yang dituntut. Salah satu contoh kata kerja operasional yang tepat adalah indikatorkisi-kisi soal nomor 9.

(8) Disajikan sebuah grafik, siswa dapat menentukan penjelasan sesuai isi grafik.

Kata kerja menentukan yang dipergunakan dalam indikator tersebut tepat karena tidak mungkin memunculkan kata kerja menjelaskan untuk soal jenis pilihan ganda. Jadi, kata kerja operasional menentukan dalam indikator kisikisi tersebut sudah tepat maknanya.

Adapun contoh penggunaan kata kerja operasional yang cukup tepat terdapat pada indikator kisi-kisi soal nomor 10. Indikator tersebut adalah sebagai berikut.

(9) Disajikan sebuah tabel, siswa dapat menentukan simpulan sesuai isi tabel".

Penggunaan kata kerja menentukan dalam indikator kisi-kisi soal tersebut cukup tepat. Artinya, penyusun kisi-kisi soal sudah mampu memberikan gambaran tentang soal yang harus dibuat oleh penyusun soal. Akan tetapi, indikator kisi-kisi soal tersebut akan lebih tepat jika menggunakan kata kerja operasional menyimpulkan saja. Selain makna katanya lebih sesuai dengan kompetensi yang dituntut, kata kerja tersebut juga lebih efektif(singkat dan jelas). Oleh karena itu, alternatif perbaikan untuk indikator soal nomor 10 adalah sebagai berikut.

(9a) Disajikan sebuah tabel, siswa dapat menyimpulkan isi tabel tersebut dengan tepat.

Atau jika tanpa stimulus menjadi,

(9b) Siswa dapat menyimpulkan isi tabel dengan tepat.

Berdasarkan ketepatan dari kelima aspek tersebut, yakni tingkat kompetensi, materi, kalimat, logika, dan kata kerja operasional, dapat disimpulkan bahwa ketepatan indikator kisi-kisi soal uji coba I bahasa Indonesia di SMP Kabupaten Wonosobo tahun 2013 termasuk kategori tepat. Hal ini tampak dari rata-rata ketepatan kelima aspek tersebut yang sebesar $86,4 \%$. Namun demikian, indikator dalam kisi-kisi soal tersebut sebenarnya masih perlu perbaikan pada aspek ketepatan kalimat, logika, dan penggunaan kata kerja operasional.

\section{Keterwakilan Setiap Kompetensi Dasar}

Setiap butir soal yang dibuat harus dapat ditelusuri indikator dan kemampuan dasarnya. Semua butir soal harus jelas dalam mengukur indikator dan kemampuan dasar tertentu. Semua indikator yang dibuat harus ada tagihan capaiannya oleh peserta didik. Artinya, semua indikator harus memiliki butir soal untuk mengukur penguasaan peserta didik terhadap indikator yang bersangkutan.

Jumlah butir soal untuk setiap indikator adalah relatif. Artinya, jumlah tersebut tergantung pada kebutuhan dan pertimbangan seperti tujuan pembelajaran, keluasan, kedalaman, urgensi, tingkat kesulitan, kesinambungan, dan pentingnya sebuah indikator sebagai prasyarat untuk menguasai kemampuan dasar, atau pentingnya sebuah indikator bagi penguasaan indikator-indikator lain dan bahkan juga mendukung penguasaan kemampuan dasar lain.

Pemerintah telah menetapkan Standar Kompetensi Lulusan (SKL) Ujian Nasional. Ketetapan pemerintah tersebut memberitahukan bahwa peserta didik selayaknya menguasai 30 kompetensi dasar, baik kompetensi membaca maupun menulis. Ketiga puluh kompetensi dasar tersebut merupakan acuan jumlah maksimal yang dijadikan dasar penghitungan keterwakilan kompetensi dasar dalam penelitian ini. Adapun keterwakilan setiap kompetensi dasar dalam kisi-kisi soal uji coba I bahasa Indonesia di SMP Kabupaten Wonosobo tahun 2013 dapat dilihat pada Tabel 3.

Tabel 3. Keterwakilan Setiap Kompetensi Dasar

\begin{tabular}{ccc}
\hline No. & Kategori KD & Jumlah KD \\
\hline 1. & Terwakili & 27 \\
2. & Cukup Terwakili & 3 \\
3. & Tidak Terwakili & - \\
& Jumlah & 30 \\
\hline
\end{tabular}

Dari tabel tersebut dapat diketahui bahwa jumlah KD yang berkategori terwakili sebesar $90 \%$ dari total KD yang diujikan. Hanya ada $3 \mathrm{KD}$ yang termasuk kategori cukup terwakili dan tidak ada KD yang tidak terwakili. Ketiga kompetensi dasar yang termasuk kategori cukup terwakili adalah mengidentifikasi isi dan bagian suatu teks, mengidentifikasi unsur in- 
trinsik puisi, dan menulis surat dinas. Jumlah soal untuk ketiga KD tersebut masih kurang sebanding dengan keluasan cakupan materi. Berdasarkan penghitungan rata-rata skor, tingkat keterwakilan KD dalam kisi-kisi soal uji coba I bahasa Indonesia termasuk dalam kategori sangat terwakili $(96,7 \%)$.

\section{Kesesuaian antara Kisi-kisi Soal dan Soal}

Kesesuaian antara kisi-kisi soal dan soal uji coba I bahasa Indonesia di SMP Kabupaten Wonosobo tahun 2013 dapat dilihat pada Tabel 4.

Tabel 4. Kesesuaian antara Kisi-kisi Soal dan Soal

\begin{tabular}{ccc}
\hline No. & Kategori & Jumlah Indikator \\
\hline 1. & Sesuai & 32 \\
2. & Cukup Sesuai & 15 \\
3. & Tidak Sesuai & 3 \\
& Jumlah & 50 \\
\hline
\end{tabular}

Berdasarkan hasil telaah diketahui bahwa tingkat kesesuaian antara kisi-kisi soal dan soal uji coba I bahasa Indonesia di SMP Kabupaten Wonosobo tahun 2013 termasuk kategori sesuai. Hasil penghitungan rata-rata kesesuaian antara kisi-kisi soal dan soal adalah sebesar $86 \%$. Dengan demikian, sebenarnya masih ada kekurangsesuaian atau bahkan ketidaksesuaian antara kisi-kisi soal dan soal. Hal ini tampak jelas dari Tabel 4 tersebut. Pembahasan bentuk kesesuaian antara kisi-kisi soal dan soal adalah sebagai berikut.

\section{Kisi-kisi Soal dan Soal yang Sesuai}

Kesesuain antara kisi-kisi soal dan soal dapat terlihat dari adanya kesamaan antara indikator kisi-kisi soal dan soal. Contoh indikator yang sesuai seperti yang terdapat pada kisi-kisi soal dan soal nomor 1 .

Kisi-kisi soal:

Disajikan sebuah paragraf, siswa dapat menentukan gagasan utama paragraf tersebut.

Soal:

Perhatikan paragraf berikut! Gagasan utama paragraf tersebut adalah ....

Kisi-kisi soal menyebutkan adanya sajian sebuah paragraf dan kompetensi yang harus dikuasai adalah menentukan gagasan utama dari paragraf tersebut. Soal ternyata menyediakan sebuah paragraf lalu kompetensi yang diminta adalah menentu-kan gagasan utama paragraf. Jadi, antara kisi-kisi soal dan soal ada kesesuaian.

\section{Kisi-kisi Soal dan Soal yang Kurang Sesuai}

Bentuk kekurangsesuaian antara kisikisi soal dan soal uji coba I bahasa Indonesia Kabupaten Wonosobo tahun 2013 adalah terdapat pada soal nomor 31 dan 37. Berikut kisi-kisi soal dan soal nomor 31.

Kisi-kisi soal:

Disajikan surat pembaca tentang lingkungan yang tidak nyaman yang dirumpangkan, siswa dapat menentukan kalimat Soal: lengkapnya.

Bacalah ilustrasi berikut! Kalimat surat pembaca yang tepat sesuai dengan ilustrasi tersebut adalah ....

Kekurangsesuaian yang terdapat dalam kisi-kisi soal dan soal tersebut dapat ditinjau dari dua hal. Pertama, kisi-kisi soal menyebutkan adanya sajian surat pembaca, artinya penulis soal seharusnya memberikan contoh konkrit sebuah surat pembaca, baik yang berada di koran atau pun majalah. Namun dalam soalnya, penulis soal hanya menyajikan suatu ilustrasi saja dan bukanlah surat pembaca. Kedua, kisi-kisi soal me-nyatakan ada bagian yang dirumpang$k a n$, tetapi penulis soal meminta untuk membuat surat pembaca. Berdasarkan kedua hal tersebut, ada kekurangsesuaian antara kisi-kisi soal dan soal nomor 31 .

\section{Kisi-kisi Soal dan Soal yang Tidak Sesuai}

Bentuk ketidaksesuaian antara kisi-kisi soal dan soal uji coba I bahasa Indonesia Kabupaten Wonosobo tahun 2013 terdapat pada 3 soal, yaitu soal nomor 3, 46, dan 47 . Bentuk ketidaksesuaian pada soal nomor 46 dan 47 adalah terletak pada hal yang sama. Materi soal nomor 46 dan 47 adalah puisi. Ketidaksesuaian tersebut dikarenakan (1) kebenaran isi materi yang diragukan, (2) ketidaksesuaian antara materi dengan jenjang pendidikan, dan (3) kosakata yang terlalu sulit. 
Bahasa yang digunakan dalam puisi soal nomor 46 merupakan contoh ketidaksesuaian soal. Berikut kutipan puisi soal nomor 46 dari soal uji coba I bahasa Indonesia di SMP Kabupaten Wonosobo tahun 2013.

berdiri sepi menatap rembulan ditemani sang kekasih malam hamparan mutiara bersinar terang tanpa bunyi rembulan malam

menuntun diri mengharap penerangan wujud nyata tanpa bayangan mensyukuri indahnya angin meniti air dari rembulan

Larik ke-2 dan ke-4 bait pertama dalam puisi tersebut memiliki makna yang membingungkan. Begitu pun tiga larik pada bait kedua, yaitu larik kedua, ketiga, dan keempat. Pemahaman terhadap larik-larik tersebut sangatlah sulit, sehingga larik puisi tersebut tidak sesuai untuk peserta didik tingkat SMP.

\section{Capaian Daya Serap Setiap Kompetensi Dasar}

Pemerintah telah menetapkan standar ketuntasan minimal bahwa setiap siswa harus dapat menguasai minimal $75 \%$ dari seluruh kompetensi dasar yang dipelajari dan diujikan. Artinya, jika setelah diujikan penguasaan suatu kompetensi dasar tidak mencapai besaran tersebut, pembelajaran terhadap kompetensi dasar tersebut belum bisa dikatakan tuntas. Ketuntasan tersebut tentunya dapat dinilai baik secara individual maupun klasikal. Dalam penelitian ini, analisis daya serap dilaksanakan secara klasikal.

Capaiandaya serap kompetensi dasar yang dijadikan dasar perhitungan adalah besaran daya serap setiap sekolah. Capaian daya serap setiap kompetensi dasar didapat dengan menghitung rata-rata daya serap setiap indikator dalam suatu kompetensi dasar. Kompetensi dasar yang hanya terdiri atas satu indikator, capaian daya serapnya didasarkan pada capaian daya serap satu indikator tersebut. Adapun kompetensi dasar yang terdiri atas beberapa indikator, capaian daya serapnya diperoleh dengan menghitung rata-rata dari capaian semua indikatornya. Adapun capaian daya serap setiap kompetensi dasar dari soal uji coba I bahasa Indonesia di SMP Kabupaten Wonosobo tahun 2013 dapat dilihat pada Tabel 5.

Tabel 5. Capaian Daya Serap Setiap Kompetensi Dasar

\begin{tabular}{clcc}
\hline No. & Tingkatan & $\begin{array}{c}\text { Jumlah } \\
\text { KD }\end{array}$ & $\begin{array}{c}\text { Jumlah } \\
\text { Soal }\end{array}$ \\
\hline 1. & Sangat Tinggi & - & - \\
2. & Tinggi & 5 & 7 \\
3. & Sedang & 7 & 12 \\
4. & Rendah & 7 & 15 \\
5. & Sangat Rendah & 11 & 16 \\
& Jumlah & 30 & 50 \\
\hline
\end{tabular}

Dari tabel tersebut dapat diketahui bahwa capaian daya serap untuk kompetensi dasar yang berkategori sangat tinggi tidak ditemukan. Sebaliknya, capaian daya serap untuk kompetensi dasar yang berkategori sangat rendah jumlahnya paling besar. Berdasarkan hasil rata-rata penguasaan capaian daya serap untuk semua kompetensi dasar yang sebesar $56,89 \%$, dapat disimpulkan bahwa capaian daya serap kompetensi dasar yang diujikan dalam soal uji coba I bahasa Indonesia di SMP Kabupaten Wonosobo tahun 2013 termasuk dalam kategori rendah.Secara lebih rinci, pembahasan capaian daya serap setiap kompetensi dasar adalah sebagai berikut.

\section{Capaian Daya Serap Kompetensi Dasar Kategori Tinggi}

Capaian daya serap kompetensi dasar yang termasuk dalam kategori tinggi sebesar $14 \%$. Jumlah kompetensi dasarnya terdiri atas $5 \mathrm{KD}$ dengan 7 soal. Kelima kompetensi dasar tersebut terdiri atas 4 kompetensi dasar keterampilan berbahasa dengan 6 soal, dan 1 kompetensi dasar keterampilan bersastra dengan 1 soal. Capaian daya serap kompetensi dasar yang dimaksud ditunjukkan pada Tabel 6.

Beberapa soal untuk kompetensi dasar yang capaian daya serapnya berkategori tinggi termasuk dalam kategori soal yang kurang baik. Beberapa soal tersebut adalah soal untuk KD menemukan masalah utama dari beberapa berita yang bertopik sama dan membedakan fakta dan opini dalam teks iklan. Kekurangbaikan berasal dari segi materi dan bahasanya. Untuk 
soal nomor 3, ketidakbaikan itu disebabkan oleh tidak adanya jawaban yang paling tepat, sehingga soal tersebut dianulir. Adapun untuk soal nomor 6, kekurangbaikan hanya disebabkan oleh ketidakjelasan materi pada kisi-kisi saja, sedangkan materi pada soal sudah jelas.

Tabel 6. Capaian Daya Serap Kompetensi Dasar Kategori Tinggi

\begin{tabular}{clc}
\hline No. & \multicolumn{1}{c}{ Kompetensi Dasar } & $\begin{array}{c}\text { Rata-rata } \\
\text { Daya Serap } \\
\text { KD }(\%)\end{array}$ \\
\hline 1. & $\begin{array}{l}\text { Menemukan masalah } \\
\text { utama dari beberapa } \\
\text { berita yang bertopik } \\
\text { sama** }\end{array}$ & 86,26 \\
2. $\begin{array}{l}\text { Menulis pesan singkat } \\
\text { 3. }\end{array}$ & 84,45 \\
& $\begin{array}{l}\text { Menulis petunjuk } \\
\text { melalukan sesuatu }\end{array}$ & 80,28 \\
4. $\begin{array}{l}\text { Membedakan antara } \\
\text { fakta dan opini dalam }\end{array}$ & 80,72 \\
teks iklan* & \\
5. Menulis pantun & 84,16 \\
\hline
\end{tabular}

Keterangan:

*) soal berkategori kurang baik

**) soal berkategori tidak baik

(...) soal yang berkategori kurang baik/tidak baik

Capaian Daya Serap Kompetensi Dasar Kategori Sedang

Tabel 7. Capaian Daya Serap Kompetensi Dasar Kategori Sedang

\begin{tabular}{|c|c|c|}
\hline No. & Kompetensi Dasar & $\begin{array}{c}\text { Rata-rata } \\
\text { Daya Serap } \\
\text { KD }(\%)\end{array}$ \\
\hline 1. & Menulis berita & 78,69 \\
\hline 2. & Menulis buku harian & 77,71 \\
\hline 3. & Menulis surat pribadi & 72,89 \\
\hline 4. & $\begin{array}{l}\text { Menulis teks } \\
\text { pengumuman }\end{array}$ & 66,70 \\
\hline 5. & $\begin{array}{l}\text { Mengenali ciri-ciri } \\
\text { umum puisi }\end{array}$ & 75,85 \\
\hline 6. & $\begin{array}{l}\text { Mengidentifikasi unsur } \\
\text { intrinsik teks drama }\end{array}$ & 71,55 \\
\hline 7. & Menulis naskah drama & 66,38 \\
\hline
\end{tabular}

Capaian daya serap kompetensi dasar yang termasuk dalam kategori sedang sebesar $14 \%$. Jumlah kompetensi dasarnya terdiri atas
$7 \mathrm{KD}$ dengan 12 soal. Ketujuh kompetensi dasar tersebut terdiri atas 4 kompetensi dasar keterampilan berbahasa dengan 4 soal, dan 3 kompetensi dasar keterampilan bersastra dengan 5 soal. Adapun capaian daya serap kompetensi dasar yang dimaksud ditunjukkan pada Tabel 7.

\section{Capaian Daya Serap Kompetensi Dasar Kategori Rendah}

Capaian daya serap kompetensi dasar yang termasuk dalam kategori rendah sebesar $30 \%$. Jumlah kompetensi dasarnya terdiri atas $7 \mathrm{KD}$ dengan 15 soal. Ketujuh kompetensi dasar tersebut terdiri atas 6 kompetensi dasar keterampilan berbahasa dengan 10 soal, dan 1 kompetensi dasar keterampilan bersastra dengan 5 soal. Adapun capaian daya serap kompetensi dasar yang dimaksud ditunjukkan pada Tabel 8.

Tabel 8. Capaian Daya Serap Kompetensi Dasar Kategori Rendah

\begin{tabular}{llc}
\hline No. & \multicolumn{1}{c}{ Kompetensi Dasar } & $\begin{array}{c}\text { Rata-rata } \\
\text { Daya Serap } \\
\text { KD }(\%)\end{array}$ \\
\hline 1. & Menulis surat dinas* & 62,36 \\
2. & Menulis iklan baris & 61,19 \\
3. & Meresensi & 62,00 \\
& pengetahuan \\
4. & Menulis surat pembaca* & 59,26 \\
5. & Mengubah sajian grafik, & 55,10 \\
& $\begin{array}{l}\text { tabel, atau bagan } \\
\text { 6. }\end{array}$ & Menulis karya ilmiah \\
& sederhana \\
7. & Menceritakan kembali \\
& cerita anak yang dibaca* \\
\hline
\end{tabular}

Keterangan:

*) soal berkategori kurang baik

(...) soal yang berkategori kurang baik

Beberapa soal untuk kompetensi dasar yang capaian daya serapnya berkategori rendah termasuk dalam kategori soal yang kurang baik. Beberapa soal tersebut adalah soal untuk KD menulis surat dinas, menulis surat pembaca, dan menceritakan kembali cerita anak yang dibaca. Kekurangbaikan berasal dari segi materi dan bahasanya. Soal nomor 16, 17 dan 31 termasuk kategori kurang baik dari aspek 
materi. Kekurangsesuaian tersebut disebabkan adanya perbedaan materi dalam indikator soal yang berada di kisi-kisi dengan materi soal saja. Adapun soal nomor 30 termasuk kategori kurang baik dari aspek bahasa. Kekurangbaikan tersebut berwujud adanya bagian kalimat indikator soal yang ambigu.

\section{Capaian Daya Serap Kompetensi Dasar Kat- egori Sangat Rendah}

Tabel 9. Capaian daya Serap Kompetensi Dasar Kategori Sangat Rendah

\begin{tabular}{|c|c|c|}
\hline No. & Kompetensi Dasar & $\begin{array}{c}\text { Rata-rata } \\
\text { Daya Serap } \\
\text { KD }(\%)\end{array}$ \\
\hline 1 & $\begin{array}{l}\text { Menyimpulkan isi } \\
\text { bacaan }\end{array}$ & 50,40 \\
\hline 2. & $\begin{array}{l}\text { Menulis teks pidato/ } \\
\text { ceramah/khotbah* }\end{array}$ & 41,33 \\
\hline 3. & Menyunting karangan & 41,09 \\
\hline 4. & $\begin{array}{l}\text { Mengungkapkan hal- } \\
\text { hal yang dapat } \\
\text { diteladani dari buku } \\
\text { biografi* }\end{array}$ & 38,74 \\
\hline 5. & $\begin{array}{l}\text { Menulis rangkuman isi } \\
\text { buku ilmu } \\
\text { pengetahuan popular }\end{array}$ & 34,06 \\
\hline 6. & Menulis laporan & 32,00 \\
\hline 7. & $\begin{array}{l}\text { Mendeskripsikan } \\
\text { tempat atau arah dalam } \\
\text { konteks yang } \\
\text { sebenarnya* }\end{array}$ & 29,32 \\
\hline 8. & $\begin{array}{l}\text { Menulis puisi bebas } \\
\text { dengan } \\
\text { memperhatikan unsur } \\
\text { persajakan** }\end{array}$ & 32,93 \\
\hline 9. & $\begin{array}{l}\text { Menulis puisi bebas } \\
\text { dengan menggunakan } \\
\text { pilihan kata yang } \\
\text { sesuai** }\end{array}$ & 27,26 \\
\hline 10 & $\begin{array}{l}\text { Membandingkan } \\
\text { karakteristik novel } \\
\text { angkatan 20-30 an* }\end{array}$ & 27,15 \\
\hline 11. & $\begin{array}{l}\text { Menulis slogan/poster } \\
\text { untuk berbagai } \\
\text { keperluan* }\end{array}$ & 6,48 \\
\hline
\end{tabular}

Keterangan:

*) soal berkategori kurang baik

**) soal berkategori tidak baik

(...) nomor soal yang berkategori kurang baik/tidak baik

Capaian daya serap kompetensi dasar yang termasuk dalam kategori sangat rendah sebesar 37\%. Jumlah kompetensi dasarnya terdiri atas $11 \mathrm{KD}$ dengan 16 soal. Kesebelas kompetensi dasar tersebut terdiri atas 7 kompetensi dasar keterampilan berbahasa dengan 12 soal, dan 4 kompetensi dasar keterampilan bersastra dengan 4 soal. Adapun capaian daya serap kompetensi dasar yang dimaksud ditunjukkan pada Tabel 9.

Dari kesebelas kompetensi dasar dengan daya serap kategori sangat rendah, hanya ada 4 kompetensi dasar yang soalnya berkategori baik. Soal berkategori baik tersebut berjumlah 7 soal. Adapun soal untuk 7 kompetensi dasar lainnya berkategori kurang baik dan tidak baik. Soal yang berkategori kurang baik sebanyak 7 soal, dan soal yang berkategori tidak baik sebanyak 2 soal.

Kategori kurang baik pada soal-soal dengan capaian daya serap sangat rendah disebabkan oleh aspek materi dan konstruksi yang tidak terpenuhi. Soal yang berkategori kurang baik pada aspek materi adalah soal nomor 4, 5, 21, 34, 37 dan 38. Adapun soal yang kurang baik dari aspek konstruksi adalah soal nomor 12. Soal nomor 4, 5, dan 34 kurang baik karena ketepatan kunci jawaban diragukan, sementara soal nomor 21, 37, dan 38 karena adanya perbedaan materi antara yang berada di indikator soal dan soal. Kekurang- baikan konstruksi soal nomor 12 adalah letak gambar yang masih membingungkan.

Soal nomor 46 dan 47 termasuk kategori soal tidak baik. Ketidakbaikan disebabkan oleh adanya 2 persyaratan pada masing-masing aspek materi dan bahasa yang tidak terpenuhi. Pada aspek materi, kedua soal tersebut diragukan kebenaran isi materinya secara keilmuan dan kesesuaian isi materi dengan jenjang kelas. Pada aspek bahasa, kedua soal tersebut bahasanya sulit dipahami dan kosakata tidak umum.

Berdasarkan pembahasan hasil penelitian tentang capaian daya serap setiap kompetensi dasar dan kategori kualitas soal dapat disimpulkan bahwa kategori capaian daya serap setiap kompetensi dasar sangat berhubungan dengan kategori kualitas soal. Tinggi rendahnya daya serap berhubungan dengan baik dan tidaknya kualitas soal. 


\section{SIMPULAN}

Berdasarkan kajian teori, hasil penelitian, dan pembahasan dapat diperoleh simpulan sebagai berikut. (1) ketepatan indikator kisi-kisi soal uji coba I bahasa Indonesia Kabupaten Wonosobo tahun 2013 termasuk dalam kategori tepat yaitu sebesar $86,4 \%$. Adapun rincian ketepatan untuk setiap kategori yaitu sangat tepat sebesar $22 \%$, tepat sebesar $68 \%$, cukup tepat sebesar $8 \%$, kurang tepat sebesar $2 \%$, dan tidak tepat sebesar0\%. Adapun ketepatan untuk tiap aspek adalah tingkat kompetensi sebesar 99,3\%, materi sebesar $97,3 \%$, kalimat sebesar $85,3 \%$, logika sebesar $77,3 \%$, dan kata kerja operasional sebesar 73,3\%; (2) keterwakilan setiap kompetensi dasar dalam kisi-kisi soal uji coba I bahasa Indonesia Kabupaten Wonosobo tahun 2013 termasuk dalam kategori sangat terwakili yaitu sebesar 96,7\%; (3) kesesuaian antara kisikisi soal dan soal uji coba I bahasa Indonesia Kabupaten Wonosobo tahun 2013 termasuk kategori sesuai yaitu sebesar $86 \%$; dan (4) capaian daya serap untuk seluruh kompetensi dasar dalam soal uji coba I bahasa Indonesia Kabupaten Wonosobo tahun 2013 termasuk dalam kategori rendah yaitu sebesar 56,89\%. Adapun capaian setiap kompetensi dasar untuk tiap-tiap kategori yaitu sangat tinggi sebesar $0 \%$, tinggi sebesar $14 \%$, sedang sebesar $24 \%$, rendah sebesar $30 \%$, dan sangat rendah sebesar $32 \%$.

Beberapa saran dari hasil penelitian ini adalah sebagai berikut. (1) Dinas pendidikan dan MKKS SMP Kabupaten Wonosobo sebaiknya merancang mekanisme pembuatan soal yang lebih efektif; (2) pembuat kisi-kisi soal dan penyusun soal sebaiknya lebih cermat; (3) penelaah kisi-kisi soal dan soal di kabupaten sebaiknya benar-benar melakukan tugasnya secara maksimal; dan (4) guru-guru yang melaksanakan pembelajaran Bahasa Indonesia di kelas juga sebaiknya melakukan refleksi dan memperbaiki terhadap setiap pembelajaran yang telah dilakukan.

\section{DAFTAR PUSTAKA}

Akhadiah, S., Arsjad, M. G. \& Ridwan, S. H. 2004 Pembinaan Kemampuan Menulis Bahasa Indonesia. Jakarta: PT Gelora Aksara Pratama.

BNSP. 2010. Materi Bimbingan Teknis KTSP dan Soal Terstandar 2010: Panduan Pengembangan Indikator. Jakarta: Kemendikas.

Depdiknas. 2007. Panduan Penulisan Soal Pilihan Ganda. Jakarta: Pusat Penilaian Pendidikan, Balitbang.

Fives, H. \& Nicole D.B. 2013. Classroom Test Construction: the Power of a Table of Specifications. Diambil dari www. pareonline.net pada tanggal 10 Desember 2013.

Gronlund, N.E. 1998. Assessment of Student Achievement. Boston: Allyn \& Bacon.

Keraf, G. 2004. Komposisi. Ende: Nusa Indah.

Mardapi, D. 2008. Teknik Penyusunan Instrumen tes dan nontes. Yogyakarta: Mitra Cendikia.

Nurgiyantoro, B. 2012. Penilaian Pembelajaran Bahasa Berbasis Kompetensi. Yogyakarta: BPFE.

Setyawati, N. 2010. Analisis Kesalahan Berbahasa Indonesia, Teori dan Praktik. Surakarta: Yuma Pustaka.

Sudijono, A. 2006. Pengantar Evaluasi Pendidikan. Jakarta: PT Raja Grafindo Persada.

Sukardi. 2011. Metodologi Penelitian Pendidikan. Jakarta: Bumi Aksara.

Surapranata, S. 2005. Analisis, Validitas, Reliabilitas, dan Interpretasi Hasil Tes. Bandung: PT Remaja Rosdakarya.

Thorndike, R.M. \& Christ-Thorndike, T. 2010. Measurement and Evaluation in Psychology and Education. Boston: Pearson Education Inc.

Uno, H.B. \& Koni, S. 2012. Assessment Pembelajaran. Jakarta: Bumi Aksara. 